\title{
INSTANTANEOUS AND COMPOUND GROWTH ANALYSIS FOR THE CONSUMPTION AND PRODUCTION OF RICE AND ITS IMPLICATION FOR EMPOWEMENT PROGRAM IN NIGERIA
}

\author{
Justine ZAKARI ${ }^{1}$, Augustine ABAKPA ${ }^{2 *}$, Richard ORANU ${ }^{3}$, Jonathan, M., VANDU ${ }^{4}$, Adams BABANGIDA ${ }^{5}$ \\ I'Adamawa State-Nigeria (zakarijustine@gmail.com), \\ *2(Department of Economics, ECWA Academy Demsa-Nigeria, abakpaaugustine@gmail.com) \\ ${ }^{3}$ (Lincoln University College, Malaysia, (richardoranu@gmail.com) \\ ${ }^{4}$ (University of Maiduguri, Borno State, Nigeria (vandujonathan@gmail.com), \& \\ ${ }^{5}$ (Adamawa State Board of Internal Revenue, Adamawa State-Nigeria(adamsbabangida@gmail.com)
}

\section{*Corresponding Author: -}

Email:abakpaaugustine@gmail.com

\begin{abstract}
: -
This study was necessitated as a result of the existing yield gap between rice production and consumption in Nigeria. This research aimed to determine the instantaneous and compound growth rates of rice consumption and production in Nigeria over the period of 1994 to 2019 and its empowerment impact. Time series data on the aggregate rice consumption and production obtained from the database of United State Department for Agriculture (USDA) foreign agricultural service were employed in this study. A semi-log growth rate model was employed to analyze the time series data using $E$ views 8.5 and the result of the analysis showed that the instantaneous and compound growth rates(5\% and $5.13 \%)$ of rice consumption were higher than that of rice production $(4.5 \%$ and $4.6 \%)$ and this indicates that the incidence of consumption-production gap for rice in Nigeria has been an existing trend over the years and the trend would continue if appropriate measures are not put in place. The implication of this finding is that the untapped potentials of Nigeria for rice production should be exploited for the empowerment of Nigerian youths in the area of rice production and women in the area of rice processing. This research work hereby recommends that government should provide comprehensive farmer education and technical assistant, continued engagement between the federal government and the states governments and the provision of value-chain training to rice farmers in Nigeria.
\end{abstract}

Keywords: Instantaneous Growth, Compound Growth, Consumption, Production, Empowerment Program

\section{(a) $(\$)$}




\section{INTRODUCTION}

Rice as one of the most consumed staple food the world over has occupied a prominent position as a strategic crop for food security and economic development in many nations of the world. The growing demand for rice and the existing challenges to achieve global food security is a thing of concern to researchers. (Asunloye, 2020) highlighted that in 2019, the global grain production sits on the quantity production level of 2.63 billion metric tons, the production of corn and wheat was established at 1.1. Billion metric tons and 731.45 million metric tons respectively, while the rice paddy which is relevant to this study amounted to 728.07 million MMT (Statista figure, 2018) and milled quantity produced which is the core component of this research were at 499.2 MMT globally and rice emerged as the world's third most produced cereal crop behind maize and wheat respectively.

Rice is a leading staple crop in Nigeria that is cultivated and consumed in all parts of the country (Ayanwale et al., 2011). During the 1960s, Nigeria had the lowest per capita annual consumption of rice in the sub-region at an annual average of $3 \mathrm{~kg}$. Since then, Nigerian per capita consumption levels have grown significantly at $7.3 \%$ per annum (Ogundele \& Okoruwa, 2006) as cited in Oyinbo et al (2013). In Nigeria, rice has assumed a strategic position in the food basket of rural and urban households and is cultivated in virtually all of Nigeria's agro-ecological zones. The consumption for rice in Nigeria has been increasing at a much faster rate than in any other African country since the mid-1970s (Daramola 2005). Although, the paddy harvest rose from under 1 million tons in the 1970s to 4.2 million tons in 2010, production has not kept pace with demand (Oyinbo et al, 2013). There is a considerable potential for extending and intensifying rice production in the five rice-growing ecosystems found in Nigeria (plateau, rain fed plains, irrigated plains, lowlands and mangrove (Bamba et al, 2010).

Furthermore, the consumption-production gap is brought about as a result of the difference between potential and actual yields.The level of domestic rice production in Nigeria is estimated to be around 3 million metric tons while the domestic demand for rice is around 5 million metric tons which has led to a huge demand - supply gap of around 2 million metric tons of rice annually, thereby motivating the continued dependence on importation to fill the existing gap, Daramola, 2005 cited in (Babatunde, Salami \& Muhammed, 2017).

In furtherance, self-sufficiency in rice production has eluded Nigeria for a long time despite numerous efforts by the Government of Nigeria towards its realization (Umeh \& Atarboh, (2007), The importation of rice to bridge the demandsupply gap is worth $\$ 365$ billion, (Ayanwale \& Amusan, 2012) and this implies a loss of considerable foreign exchange for the country. Previous Nigerian governments have made several efforts to improve rice production in Nigeria so as to meet the increasing demand from a significant growing population. The successive government under President Goodluck Jonathan had launched massive domestic production of rice under her agricultural transformation agenda which was expected to reduce the supply-demand gap of the commodity in the country (Olugbenga \& Idris, 2015). The new government dispensation under President Mohammadu Buhari continues to make effort to improve rice production in Nigeria to meet high consumption of rice, as it was reported by BBC reporter on 12 April, 2019. Nigerian government has placed embargo on rice importation and encourages more domestic rice production through government farming grants, loans offered at affordable interest rate like the 9\% interest rate to farmers instead of the initial 14\% (Mary-Ann Russon, 2019). However, the quantity produced is far below the domestic consumption level coupled with increased cases of insecurity in the country, shrinking of Lake Chad basin and desert encroachment has affected farming adversely. Therefore, this study was undertaken with the objective to find the instantaneous and compound growth rates of rice consumption and production over the period of 1994 to 2019 and draw up relevant conclusions and recommendations.

\section{Literature Review \\ 2.1 Concept Clarification \\ 2.1.1 Instantaneous Growth rate:}

This is the slope coefficient which measures the constant proportional or relative change in dependent variable for a given change in independent variable, multiplied by 100 (Gujarati \& Porter, 2009). This simple expression, Instantaneous growth rate can be described as the growth rate that tells how fast the value of a given variable is growing at a certain instant. In other words, instantaneous growth rate is a growth rate at a point in time, which maybe quarterly or yearly.

\subsubsection{Compound Growth rate:}

This is the difference between the antilog of the slope coefficient and one, multiplied by 100 (Gujarati \& Porter, 2009). Compound growth rate can equally be described as the growth rate that defines how the value of a variable grows over the entire sample period. That is, compound growth rate is the growth rate for several years taken in aggregation.

\subsubsection{Consumption- Production gap:}

Consumption-Production gap can be described as the disequilibrium that exists between total consumption and total production.

\subsection{Challenges of Rice Production in Nigeria}

Longtau, (2003) pointed some challenges facing rice production in Nigeria. The research identified

i. Pest and Diseases: Birds, insects, mammals constitute problems to rice production in Nigeria such as weaver birds, stem borers, grasshoppers, squirrels, rats, fish while the diseases are blast, rot, rust, smut, brown spots, iron toxicity and many others. 
ii. Man Made Problems: Such as cattle encroachment, bush burning, illiteracy

iii. Poor access to funding through loans and grants to farmers, local quality of inputs and anachronistic farming, processing and storage facilities

iv. Inadequate improved seedlings which usually makes farmers apply low yielding grains

v. Poor road networks usually increase the cost to farmers in terms of bringing inputs to farms, moving out with harvested farm products to market and for further processing

vi. Environmental issues: The rise in the level of insecurity in the country from the activities of insurgents, farmers/herders' crises, banditry, kidnapping, political uncertainties are really banes to farming and production of rice in Nigeria

\subsection{Opportunities for Rice Farmers in Nigeria}

Here are opportunities in rice production as put forward by (Ukwungwu \& Abo, 2013).

i. The country is endowed with vast and fertile land area for rice cultivation. About 5 million ha could be put under cultivation out of which about $3 \mathrm{~m}$ ha are utilized.

ii. There exist favorable weather conditions in Nigeria for rice farming, the rainfall, temperature and relative humidity favors rice production

iii. Rice varieties that are adaptable to the various rice environments in the country are available. Such varieties could be sourced from National Agricultural Seed Council (NASC), Seed Companies, Agricultural Development Programs (ADPs).

\subsection{Empirical Literature}

Ayanwale, Akinyosoye, Yusuf, Oni (2011) examined the supply response of rice to price and non-price factors inclusive of policy and climate variables. An Error Correction Model in a co-integration framework was employed to test the responsiveness of supply to the factors considered. The study revealed that Rice supply in Nigeria is non-responsive to price, climate, importation and trade regulation policy.

Anyanwale \& Amusan (2014) examined the gender characteristics in the efficiency of rice production in Osun state. The research employed primary data elicited from 100 rice farmers with the aid of structured pre-tested questionnaire and analyzed using frequency counts, budgetary analysis and stochastic frontier production function. Findings showed that the majority $(62 \%)$ of the farmer were males, below 50 years of age (52\%) with only 6 years of formal education (58\%) having farming as their primary occupation $(65 \%)$ and cultivating up to 5 hectares of land $(66 \%)$. while, only $42 \%$ of the female farmers were below 50 years of age. Most (71\%) respondents had up to 6 years of formal education, cultivated up to 5 hectares $(61 \%)$ of land, few (18\%) chose farming as primary occupation.

Olugbenga e'tal (2015) researched on Trade Policy and Nigerian Rice Economy. The study evaluated three (3) trade policy regimes (the pre ban period (1970-1985), the ban period (1986-1995) and post ban period (1997-2010)) by successive government to arrest this trend. Secondary data on domestic production, demand and importation of rice from 1970 to 2010 were employed to aid in analyzing both descriptive and inferential statistical tools. The result of the Descriptive analysis showed that the mean domestic production of rice for pre ban, ban and post ban period were 728.87, 2165.82 and 6293.33 metric tons respectively. The elasticity coefficients for domestic production and demand for pre and post ban are $0.98,1.60,-0.15$ and 0.14 respectively. The study concluded that government should stimulate expansion of domestic production of rice while phasing out rice importation gradually.

Babatunde, e'tal (2017) carried out a study to determine the yield gap in rice production system in Nigeria. The research applied; Gross Margin Budgetary analysis, Stochastic Frontier, and Linear Regression Model were respectively used to estimate the profitability, technical efficiency and determinants of yield gap in both production systems. The outcome of the research showed rice production is more profitable and efficient under the irrigated rice production system than the rained rice production system.

\section{METHOLOGY}

\subsection{Source of Data}

This research employed time series data on rice consumption and milled rice production respectively in metric tons in Nigeria, spanning over the period of 1994 to 2019 which is a 26 year period and that is sufficient enough as a scope of the study. The data were elicited from the database of United State Department for Agriculture (USDA), foreign agricultural service.

\subsection{Model Specification}

A growth rate model adopted from (Gujarati and porter, 2009) and as employed by Oyinbo and Emmanuel (2012) and Oyinbo et al (2013) was utilized for the estimation of the instantaneous and compound growth rate in rice consumption and production in Nigeria over the period of 1994 to 2019.

The compound interest formula was adopted for developing the model and is expressed as:

$$
\mathrm{Yt}=\mathrm{YO}(1+\mathrm{r})^{\mathrm{t}} \text {. }
$$

Where:

$\mathrm{Y}_{\mathrm{Y}}=$ Consumption and production of rice at time $\mathrm{t}$.

$\mathrm{Y}_{0}=$ Initial value of rice consumption and production.

$\mathrm{r}=$ Compound rate of growth of rice consumption and production over time.

$\mathrm{t}=$ Time trend (1994 to 2019) 
Taking the natural logarithm of equation (1), equation (2) was derived as:

$$
\begin{aligned}
& \ln \mathrm{Y}_{\mathrm{t}}=\ln \mathrm{Y}_{0}+\operatorname{tn}(1+\mathrm{r}) \\
& \text { Let; } \beta 1=\ln \mathrm{Y} 0 \ldots \ldots \ldots \ldots \\
& \quad \beta 2=\ln (1+\mathrm{r}) \ldots \ldots \ldots \ldots
\end{aligned}
$$

Model (2) can be expressed as:

$$
\ln Y_{t}=\beta_{1}+\beta_{2} t
$$

With the addition of the stochastic (i.e. error) term Ut, the econometrics model was derived as:

$$
\ln Y_{t}=\beta_{1}+\beta_{2} t+U_{t}
$$

Where:

$\mathrm{Y}_{\mathrm{t}}=$ Rice demand and supply at time $\mathrm{t}$

$\mathrm{t}=$ Time trend (1994 to 2019)

$\beta_{1}=$ Constant term

$\beta_{2}=$ Coefficient of time variable

$\mathrm{U}_{\mathrm{t}}=$ Random term

After the estimation of equation (1), the compound rate of growth was computed by using:

$$
\mathrm{r}=\operatorname{antilog}(\beta 2)-1 \text { or } \mathrm{r}=\mathrm{e}^{\beta 2}-1
$$

Where:

$\mathrm{r}=$ compound rate of growth

$\beta_{2}=$ estimated coefficient from equation (1)

The econometrics model of the growth rate as shown in eq. (6) was estimated using E-views software.

\section{RESULT}

\subsection{Estimated Growth Model of Rice Consumption}

TABLE I, which is the least square estimation for rice consumption, gives evident analysis to this research work. The slope coefficient of 0.05 means on the average the log of $\mathrm{Yt}$ (rice consumption) has been increasing at the rate of 0.05 per year. In simplified term, rice consumption has been increasing at the rate of 5\% per year, for in a semi-log model as shown in equation (8) below, the slope coefficient measures the proportional or relative change in rice consumption for a given absolute change in the explanatory variable, time $(\mathrm{t})$ in the present case. Also, the calculated t-value for the coefficient of time $(t)$ is greater than 2 [i.e. $t \geq 2$ ] and the standard error is less than half of the coefficient of time [i.e. se $<\beta 1 / 2$ ]. Thus, the findings indicate that the relationship between rice consumption and time is statistically significant. Hence, $\mathrm{R}^{2}$ which measures the goodness has the value $=0.9765$ means that approximately $98 \%$ of the variation in $\operatorname{lnYt}$ (Rice consumption) is explained by time $(\mathrm{t})$ which was captured in the model of the study.

$$
\begin{aligned}
& \ln Y \mathrm{t}=\beta 1+\beta 2 \mathrm{t}+\mathrm{Ut} \\
& \ln Y \mathrm{t}=7.638+0.050 \mathrm{t}
\end{aligned}
$$

$$
\begin{array}{lll}
\text { se } & =(0.0244) & (0.0016) \\
\mathrm{t} & =(313.19) & (31.61) \\
\mathrm{R}^{2} & =0.9765
\end{array}
$$

Growth rate $=$ relative change $\times 100$

Growth rate $=0.05 \times 100$

Growth rate $=5 \%$ (instantaneous rate of growth)

Compound rate of growth $=$ antilog $(\beta 2)-1$

$$
\begin{aligned}
& =\operatorname{antilog}(0.050)-1 \\
& =(1.0513-1) \times 100 \\
& =0.0513 \times 100 \\
& =5.13 \%
\end{aligned}
$$


TABLE: I: Least Square Estimation for Rice Consumption

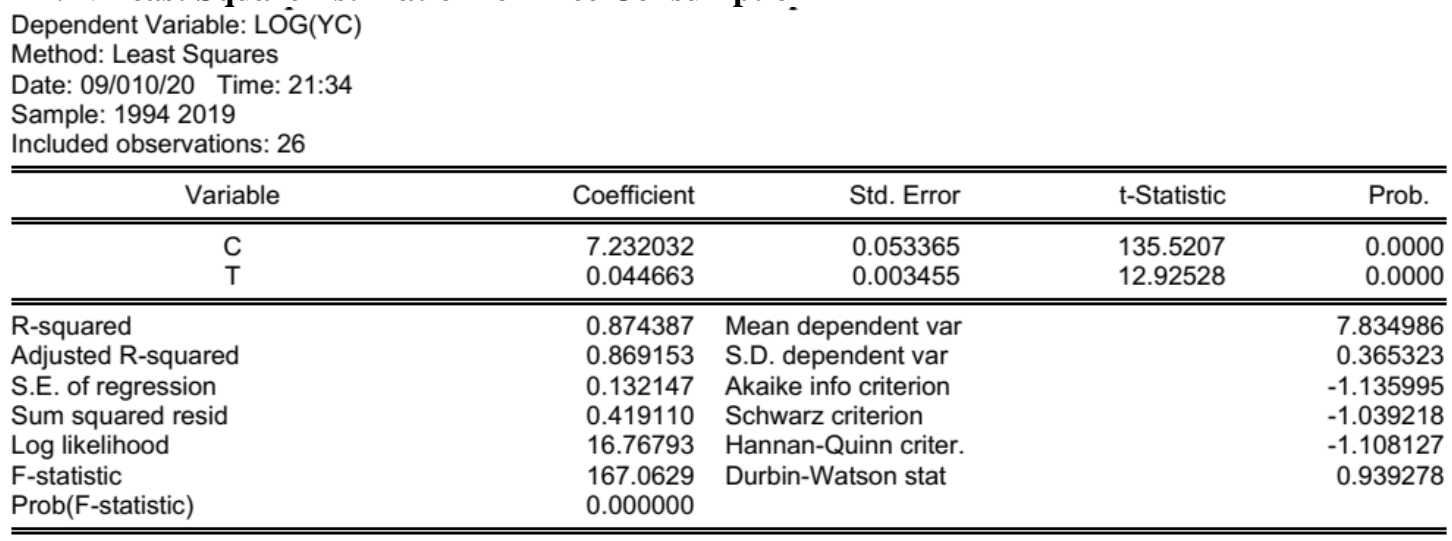

Source: Researchers' E-views Output, 2020

$Y c=$ Consumption of Rice.

\subsection{Estimated Growth Model for Rice Production}

TABLE II shows the least square estimation for rice production in Nigeria. The slope coefficient of 0.045 means on the average the log of $\mathrm{Yt}$ (rice production) has been increasing at the rate of 0.045 per year. In simple term, rice production has been increasing at the rate of $5 \%$ per year, for in a semi-log model as depicted in equation (9) below. The slope coefficient measures the proportional or relative change in rice production for a given absolute change in the explanatory variable, time $(\mathrm{t})$ in the present case. Also, the calculated $\mathrm{t}$-value for the coefficient of time $(\mathrm{t})$ is greater than 2 [i.e. $t \geq 2$ ] and the standard error is less than half of the coefficient of time [i.e. se $<\beta_{1} / 2$ ]. Thus, the findings indicate that the relationship between rice production and time is statistically significant. Hence, $\mathrm{R}^{2}$ which measures the goodness of fit of the model has the value $=0.8723$ means that, approximately $87 \%$ of the variation in lnYt (rice production) is explained by time $(\mathrm{t})$.

$$
\begin{aligned}
& \ln \mathrm{Yt}=7.232+0.045 \mathrm{t} \\
& \text { se } \quad=(0.0534) \quad(0.0035) \\
& \mathrm{t} \quad=(135.52) \quad(12.93) \\
& \mathrm{R}^{2}=0.8723
\end{aligned}
$$

Growth rate $=$ relative change $\times 100$

Growth rate $=0.045 \times 100$

Growth rate $=4.5 \%$ (instantaneous rate of growth)

Compound rate of growth $=$ antilog $(\beta 2)-1$

$$
\begin{aligned}
& =\operatorname{antilog}(0.045)-1 \\
& =(1.0460-1) \times 100 \\
& =0.0460 \times 100 \\
& =4.6 \%
\end{aligned}
$$

Therefore, the growth trend of rice consumption and production in Nigeria per annum within the period under study(instantaneous rates of growth) are $5 \%$ and $4.5 \%$ respectively and the rate of growth of rice consumption and production in Nigeria over the entire period under study(compound rates of growth) are $5.13 \%$ and $4.6 \%$ respectively. It was observed that the instantaneous and compounded growth rates of rice consumption in Nigeria over the study period were higher than that of rice production. This finding is in line with Ojoehemon et al. (2009) as well as Oyinbo et al. (2013), who noted that both rice production and consumption have vastly increased with rice demand outstripping rice production. 
TABLE: II: Least Square Estimation for Rice Production

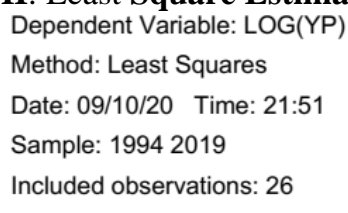

\begin{tabular}{|c|c|c|c|c|}
\hline Variable & Coefficient & Std. Error & $\mathrm{t}$-Statistic & Prob. \\
\hline C & 7.637522 & 0.024386 & 313.1877 & 0.0000 \\
\hline $\mathrm{T}$ & 0.049914 & 0.001579 & 31.60931 & 0.0000 \\
\hline R-squared & 0.976543 & Mean dependent var & & 8.311355 \\
\hline Adjusted R-squared & 0.975566 & S.D. dependent var & & 0.386323 \\
\hline S.E. of regression & 0.060388 & Akaike info criterion & & -2.702245 \\
\hline Sum squared resid & 0.087521 & Schwarz criterion & & -2.605469 \\
\hline Log likelihood & 37.12919 & Hannan-Quinn criter. & & -2.674377 \\
\hline F-statistic & 999.1483 & Durbin-Watson stat & & 0.892210 \\
\hline Prob(F-statistic) & 0.000000 & & & \\
\hline
\end{tabular}

Source: Researchers' E-views Output, 2020

$Y p=$ Rice Production

\subsection{The Need for Empowerment Program}

The higher instantaneous and compounded growth rates of rice consumption over rice production imply that there would be continuous importation of rice to bridge the consumption-production gap and this will continue to have adverse effect to the Nigerian economy. As evident from the research by Bamba et al., (2010) and cited in Oyinbo et al (2013), the cost of rice imports represents a significant amount of lost earnings for the country in terms of jobs and income. Therefore, the current situation of rice sub-sector presents an opportunity for Nigerians particularly, the youths to be empowered to undertake rice production and for women to be empowered by getting involved in rice processing. This is necessary to reduce the incidence of unemployment and poverty, and give a continued means of livelihood for the Nigerian women and equally achieve self-sufficiency in rice production. This calls for capacity building of youths on rice production and women on rice processing (Oyinbo et al, 2013).

So there is a need for resurgence into rice farming throughout the year i.e. both rainy season and dry season farming through irrigation.

\section{Conclusion}

Using time series data on rice consumption and production over the period of 1994 to 2019 , this study have been able to establish the instantaneous and compound growth rates of 5\% and 5.13\% respectively for rice consumption and $4.5 \%$ and 4.6\% for rice production using semi-log growth models. In addition, the result shows that time trend variable was significant in influencing the consumption and production of rice in Nigeria. In the estimated growth rate models, the slope coefficients of 0.050 and 0.045 for rice consumption and production respectively measures relative change in quantity consumed and produced for a given change in the value of time trend. By multiplying the relative change in quantity of rice consumed and produced respectively by hundred, we obtained the growth rate in quantity of rice consumed and produced for an absolute change in time.

The study comes to conclusion that that the consumption-production gap for rice has been an existing trend irrespective of the country's potential for rice production over the years with consumption pattern always and higher above the production based on the outcome of the result. The growth trend of the consumption and production for rice presents a viable opportunity for empowering youths in the area of rice production and women in the area of rice processing which creates potential avenue for self-employment and perpetual income because rice consumption has always indicated high demand, with other favorable factors like rise in population, favorable government policies and also the other uses of rice byproducts, this reduces the incidence of high rate of unemployment and poverty, and equally offer a sustainable means of livelihood for Nigerians.

\section{Recommendations}

This research hereby recommends the following

i. Comprehensive farmers' education/technical assistance to the youths and women through the use of extension workers should be intensified and follow up should be ensured.

ii. This research is calling relevant authorities to endeavour that credit facilities are accessible to youths and women via removal of cumbersome conditions pegged for the assessment of credit facilities,

iii. Finally, government should protect farmers and mitigate exploitation initiating appropriate pricing system related to the commodity marketing board . 


\section{References}

[1].Asunloye, A. (2020). How Rice Fared in 2019. Highlights from the Nigerian Rice Industry Report 2020. Business Day.businessday.ng

[2].Ayanwale, A.O.S., Akinyosoye, V.O., Yusuf, S.A. and Oni, A.O. (2011). Rice Supply Response in Nigeria; whither changing Policies and Climate. World Rural Observations, 3(4): 78 - 84.

[3].Ayanwale, A.B. and Amusan, C.A.(2012). Gender Analysis of Rice Production Efficiency in Osun State: Implication for the Agricultural Transformation Agenda. Paper presented at the 13th National Conference of the Nigerian Association of Agricultural Economists, Obafemi Owolowo University, Ile-Ife, Nigeria, September 25th - 27th.

[4].Bamba, I., A. Diagne, Manful, J.and Ajayi, A.( 2010). Historic Opportunities for Rice Growers in Nigeria. Grain de sel. No. 51.

[5].Babatunde, R.O.,Salami,M.F., and Muhammed,B.A.,(2017). Determinants of Yield Gap in Rained and Irrigated Rice Production Systems-Evidence from Household Survey in Kwara State, Nigeria. Journal of Agribusiness and Rural Development.1(43)

[6].Daramola, B. (2005). Government Policies and Competitiveness of Nigerian Rice Economy, Paper presented at the 'Workshop on Rice Policy and Food Security in Sub-Saharan Africa' organized by WARDA, Cotonou, Republic of Benin.

[7].Gujarati, D.N. and Porter, C. D. (2009). Basic Econometrics (5th Edition). McGraw-Hill, New York.

[8].Jolaoso M.A,Onjewu S.S.,Oladele T.O \& Maduegbunam,F.U.(2013) Industrial Applications of Rice By-Products in Nigeria. Conference Proceedings on rice-Africa, $2^{\text {nd }}$ International Conference on Rice for Food Market and Development. Nigerian National Merit Award Auditorium, Abuja,Nigeria

[9].Longtau,S.E.(2003) Multi-Agency Partnerships for Technical Change in West African Agricultural: Eco-Systems Development Organization, Jos-Nigeria for Overseas Development Institute(ODI)

[10]. Ogundele O. and Okoruwa V. (2006), Technical Efficiency Differentials in Rice Production Technologies in Nigeria, African Economic Research Consortium.

[11]. Ojehomon, V.E.T., Adebayo, S.B., Ogundele, O.O., Okoruwa, V.O., Ajayi, O., Diagne, A. and Ogunlana, O. (2009). Rice Data Systems in Nigeria: National Rice Survey.

[12]. Oyinbo, O. and Emmanuel, Y.D. (2012). Empirical Assessment of Growth Rate of Maize in the Pre - SAP, SAP and Post - SAP Periods in Nigeria, Russian Journal of Agricultural and Socioeconomic Sciences, 5(5): 23 - 27.

[13]. Oyinbo O., G. Z. Rekwot, G. A. Adegboye and D. Agbonika(2013), Growth Trend of rice demand and supply in Nigeria: an investment opportunity for youths and women empowerment ,Rice-Africa proceedings(2013),pp 73-80

[14]. Polycarp I. M. (2017). A New Paradigm to Finance Small-Holder Farmers Under a contract farming model: the case of central bank of Nigeria's Anchor Borrowers programme (ABP),Bullion Publication of the CBN, vol.41 No. 4

[15]. Ukwungwu, M.N.,Abo,M.E.(2013) Improved Rice Varieties and Adaptable Technologies for High Earning Capacity of Farmers. Conference Proceedings on rice-Africa, $2^{\text {nd }}$ International Conference on Rice for Food Market and Development. Nigerian National Merit Award Auditorium, Abuja,Nigeria

[16]. Umeh, J.C. and Atarboh, E.M. (2007). Efficiency of Rice Farmers in Nigeria: Potentials For Food Security and Poverty Alleviation. 16th International Farm Management Congress, UCC, Cork, Ireland. 15th - 20 th July 2007. pp: $613-625$.

[17]. United States Department for Agriculture Foreign Agricultural Services (USDA FAS), (2020). Database of production, supply and distribution. Available at: http://www.fas.usda.gov/psdonline/psdQuery.aspx > Accessed 15th December 2011. 